\title{
Recurrent Laryngeal Nerve Injury Secondary to Blunt Trauma; A Rarity
}

\author{
Künt Travmaya Sekonder Rekürren Laringeal Sinir Yaralanması; Nadir Bir Vaka
}

\author{
Baithma Jothi Dinesh ${ }^{1}$, Zubaidah Sharif Siti ${ }^{2}$, Lai Zen Ran Dexter ${ }^{1,3}$, Firdaus Hayati ${ }^{4}$
}

${ }^{1}$ Department of General Surgery, Hospital Queen Elizabeth, Ministry of Health Malaysia, Kota Kinabalu, Sabah, Malaysia

2 Department of Breast and Endocrine, Hospital Queen Elizabeth2, Ministry of Health Malaysia, Kota Kinabalu, Sabah, Malaysia

${ }^{3}$ Department of Surgery, Faculty of Medicine, Universiti Kebangsaan Malaysia, Kuala Lumpur, Malaysia

${ }^{4}$ Department of Surgery, Faculty of Medicine and Health Sciences, Universiti Malaysia Sabah, Sabah, Malaysia

\section{ABSTRACT}

Recurrent laryngeal nerve (RLN) injury is rarely seen following trauma. Trauma can be penetrating or blunt injury. Following the acute event, the most common presentation is hoarseness of voice. Herein we present a case of recurrent laryngeal nerve injury noticed after a blunt trauma. Indirect laryngoscopy helps to identify and diagnose vocal cord palsy while Computed Tomography (CT) scan of neck helps to evaluate the extent of injury as well as to identify the primary cause of the injury. Patient morbidity can be reduced with prompt diagnosis and management.

Key Words: Laryngeal nerve, trauma, vocal cords

Received: 03.19.2017

Accepted:02.21.2018

\section{ÖZET}

Travma sonrası rekürren laringeal sinir (RLN) hasarı nadiren görülür. Travma, penetran veya künt yaralanma olabilir. Akut olayı takiben, en yaygın bulgu ses kısıklığıdır. Burada künt travma sonrası fark edilen rekürren laringeal sinir hasarı olgusunu sunuyoruz. Indirekt laringoskopi, vokal kord paralizisinin belirlenmesine ve teşhis edilmesine yardımcı olurken, Bilgisayarlı Tomografi (BT), yaralanmanın boyutunu değerlendirmek ve yaralanmanın birincil nedenini tanımlamak için yardımcı olur. Hasta morbiditesi hızlı teşhis ve yönetim ile azaltılabilir.

Anahtar Sözcükler: Laringeal sinir, travma, ses telleri

Geliş Tarihi: 19.03.2017

Kabul Tarihi:21.02.2018

\section{INTRODUCTION}

Recurrent laryngeal nerve (RLN) injury is a common complication following thyroid surgery at a rate of $1.8 \%$, however it is rarely seen following a trauma (1). Till date, no exact figure has been reported of such injury worldwide. RLN has both motor and sensory components. It supplies all of the intrinsic muscles of the larynx except the cricothyroid muscle (the thyroarytenoid, posterior and lateral cricoarytenoid, and the arytenoid muscles) (1). Left RLN arises at the level of the aortic arch, while the right RLN begins anterior to the right subclavian artery. Both these nerves ascend along the tracheoesophageal groove and frequently branch outside of the larynx (1).

Trauma can be either penetrating or blunt injury (2). The first step in managing these patients is to establish adequate airway. If severe injury is suspected due to trauma, an emergency tracheostomy may necessitate (3). Following the acute period, the most common presentation is hoarseness of voice. Other clinical symptoms a patient may experience include dyspnea, globus sensation or cough (3).
In case of unilateral vocal cord palsy, patient may experience breathlessness, weakness of voice, difficulty in swallowing (4). When patient presented with such symptoms, it is important to ascertain the cause and diagnosis. Various modalities are available in diagnosing RLN injury (1). Following a diagnosis, treatment should then be initiated promptly. Treatment option varies according to the severity of injury.

\section{CASE REPORT}

A 17-year-old male had a motor vehicle accident. He was the motorbike rider and was involved in head on collision with a car. He could not recall the exact mechanism of injury. He developed neck swelling a day after the trauma (Figure 1) and it was not increasing in size. As the swelling ensues, patient claims to be having hoarseness of voice. The hoarseness was associated with choking episodes after meal. Upon assessment by otorhinolaryngology (ORL) team, indirect laryngoscopy showed left vocal cord palsy with the left vocal cord in the paramedian position. 
However, there was no mucosal oedema and the other structures were normal. Intravenous (IV) dexamethasone was started along with mecobalamin.

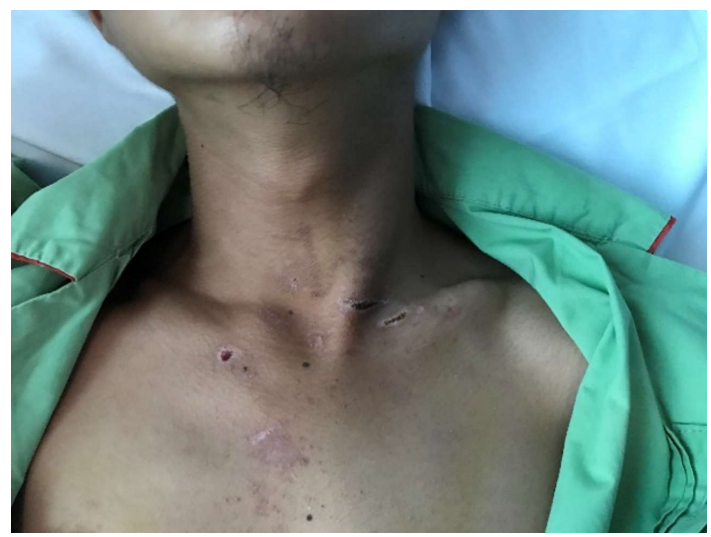

Figure 1: External image of trauma sustained by patient

Further imaging was arranged and a Computed Tomography (CT) scan of the neck was done. It revealed a large left thyroid hematoma measuring $3.5 \times 2.5$ $x 4.2 \mathrm{~cm}$ extending to superior mediastinum with deviation of trachea to the right (Figure 2(a) and 2(b)). There was vocal cord palsy with prominent vestibule but no evidence of surrounding oedema or mucosal irregularity.

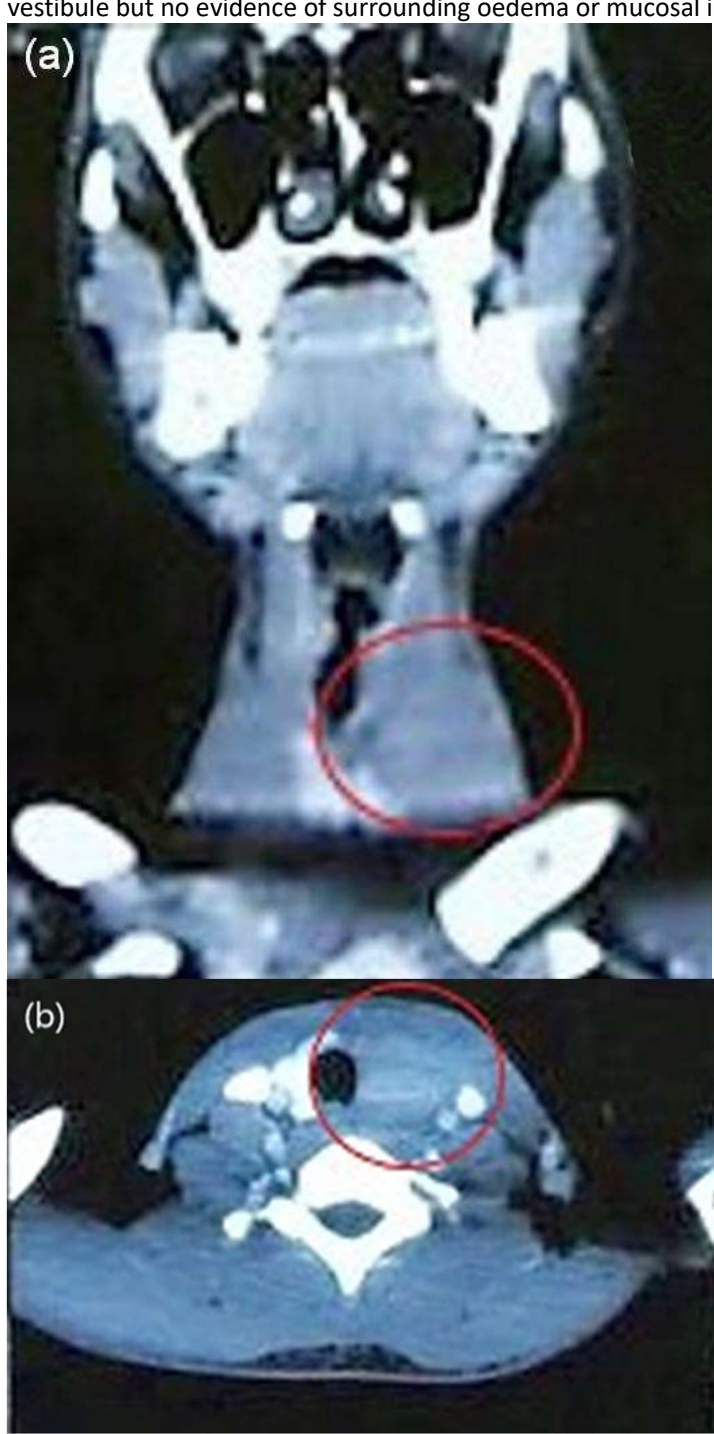

Figure 2(a): Computed Tomography (coronal view) shows left thyroid hematoma (red circle). 2(b): Computed Tomography (axial view) shows left thyroid hematoma (red circle)

He was initially planned for surgical neck exploration. However his symptoms were slowly improving with steroid and bedside swallowing test showed no choking episode. He had no symptoms and signs of hyperthyroidism in which it was proven by his thyroid function test.
Repeated laryngoscopy 4-days post trauma revealed persistent left vocal cord palsy with right vocal cord compensation. Patient was allowed orally and was tolerating well. Follow-up laryngoscopy 1-month time post trauma showed resolved vocal cord palsy. Subsequently his voice was back to normal and neck swelling had subsided.

\section{DISCUSSION}

RLN injury following a blunt trauma has rarely been reported worldwide. It can occur either through blunt or penetrating trauma (2). Blunt trauma to the neck can happen due to strike to anterior neck or by strangulation. Other form of trauma may include hematoma which compresses on the nerve as seen in our case study (4). Penetrating injury can be a form of direct injury to the nerve or the muscles involve in phonation. Apart from RLN, isolated thyroid gland haemorrhage also can develop after direct impact to the neck and it is uncommon (5). Laryngeal injury happens in less than $2 \%$ and it may affect the mucosa or cartilaginous skeleton causing changes in voice and airway compromise $(6,7)$.

During the initial assessment, it is of essential that patient's airway is not compromised due to the injury. This is of utmost importance as airway may be compromised with enlarging neck hematoma. This was seen in one of the case study as patient required emergency tracheostomy to maintain the airway (7). Further investigation then needed to help to ascertain the cause and extent of injury. Indirect or direct laryngoscopy has been the mainstay modality in diagnosing a laryngeal trauma (1,3). By performing an indirect laryngoscope, we can visualise the vocal cord mobility, mucosal injury, any forms of hematoma or any distortion of the lumen (1). As seen in this case, there was isolated left vocal cord palsy and there were no other injuries noted.

Following an indirect laryngoscope, the next modality of investigation includes performing a CT scan. CT scan is effective in detecting any mucosal or cartilaginous injury or any other injury to the surrounding structures which can help contribute to patient's symptoms (5). With CT imaging, certain diagnosis such arytenoid subluxation or laryngeal cartilage fractures can be diagnosed $(2,3)$. We did a CT scan in this case as it helped pick up diagnosis of a large left thyroid hematoma causing left vocal cord palsy. No other structures were found to be abnormal. Complications such as hyperthyroidism and thyroid storm have been reported to occur after trauma due to the efflux of thyroid hormones but it is mostly transient (8).

Other modalities of investigation include performing Electromyography (EMG) activity. EMG of both the extrinsic and intrinsic laryngeal muscles helps to ascertain recurrent and/ or superior laryngeal nerve injury (1). This however is rarely performed due to invasiveness of the procedure. The same applies to the patient in this case as no EMG was performed on him.

There are many types of treatment method for laryngeal nerve injury depending on severity of the trauma. Modalities of treatment include medication, voice therapy, vocal cord augmentation and reinnervation procedure $(1,4)$. Pharmacotherapy includes glucocorticoids as seen in this case (4). The mainstay of the conservative management in RLN injury is to allow spontaneous regeneration. This can allow subclinical innervation of the laryngeal muscles thus preventing atrophy and fibrosis of the laryngeal muscles (4). This patient was prescribed with IV Dexamethasone for 3 days with additional of methylcobalamin. Based on an animal study, methylcobalamin has proven to improve the expression of growth associated protein 43 and S100 protein and $\beta I I I$ tubulin for the recovery of the injured nerve (9). There are other methods to address this problem however they were deemed invasive and require a lot of cooperation from the patient.

Some cases have used vocal cord augmentation, which include injection to the thyroarythenoid mucle, medialization laryngoplasty, arytenoid adduction, cricothyroid subluxation (1). Reinnervation procedure include primary end-toend anastomosis, ansa cervicalis to RLN anastomosis and primary interposition graft $(1,4)$. These procedures are rarely performed and are indicated in severe RLN injuries. But most of these treatments are usually done after thyroid surgery by the ORL team.

As highlighted above, this patient sustained RLN injury following a blunt trauma. However no laryngeal injury noted in this case as per indirect laryngoscopy. CT scan showed large thyroid hematoma which compresses on the larynx. The possible postulation for his RLN injury could be from thyroid hematoma or mild laryngeal injury. Patient's condition improved after IV steroid injection and did not require any further intervention. 


\section{CONCLUSION}

Isolated Recurrent Laryngeal Injury following a blunt trauma is a very rare phenomenon and has not been reported as many compared to iatrogenic nerve injury after thyroid surgery. Each case has wide range of complication and requires different management as mentioned in this case. In cases of blunt RLN injury, conservative approach can be considered provided the patient is stable with patent airway. However, if major complication arises, more invasive approach might be necessary.

\section{Conflict of interest}

No conflict of interest was declared by the authors.

\section{Acknowledgement}

We would like to thank the Director General of Health Malaysia for giving the permission to publish this article. The authors claim to have no financial interest in the commercial products in this study.

\section{REFERENCES}

1. Lynch J, Parameswaran R, Management of unilateral recurrent laryngeal nerve injury after thyroid surgery: A review. Head Neck. 2017;39:1470-8

2. Schroeder $U$, Motzko $M$, Wittekindt $C$, et al. Hoarseness after laryngeal blunt trauma: a differential diagnosis between an injury to the external branch of the superior laryngeal nerve and an arytenoid subluxation. A case report and literature review. Eur Arch Otorhinolaryngol. 2003;260:304-7

3. Tuzuner A, Demirci S, Aydogan F, et al. Recurrent laryngeal nerve palsy following blunt trauma of lateral neck. Austin J Surg. 2014;1: 1021

4. Jiang $Y$, Gao B, Zhang $X$, et al. Prevention and treatment of recurrent laryngeal nerve injury in thyroid surgery. Int J Clin Exp Med 2014;7:101-7

5. Lemke J, Schreiber MN, Henne-Bruns D, et al. Thyroid gland hemorrhage after blunt neck trauma: case report and review of the literature. BMC Surgery. 2017;17:115

6. Łochowski MP, Rębowski M, Kozak J, et al. Laryngeal laceration after blunt neck trauma in a football player. Kardiochirurgia i Torakochirurgia Polska. 2018;15:57-8

7. Manzoor L, Mohammed L, Imtiyaz N, et al. Bilateral recurrent laryngeal nerve palsy following blunt neck trauma. Indian J. Otolaryngol. Head Neck Surg. 2007;59:298-9

8. Saylam B, Çomçali B, Ozer MV, et al. Thyroid gland hematoma after blunt neck trauma. Western Journal of Emergency Medicine. 2009;10:247-9

9. Liao WC, Wang YJ, Huang MC, Tseng GF. Methylcobalamin facilitates collateral sprouting of donor axons and innervation of recipient muscle in end-to-side neurorrhaphy in rats. PLoS One. 2013;8:e76302 